DOI: $\underline{10.34305 / \text { gemic.v1i1.319 }}$

\title{
THE OUTCOME OF PMTCT GUIDELINE IMPLEMENTATION TOWARDS THE PROGRAM PERFORMANCE FOR THE ELIMINATION OF HIV TRANSMISSION FROM MOTHER TO CHILD IN DENPASAR CITY
}

\author{
Lely Wahyuniar \\ UNAIDS Indonesia \\ wahyuniarl@unaids.org
}

\begin{abstract}
UNAIDS report on the level of HIV transmission from mother to child shows that Indonesia is in the highest rank in the world. This study aims to conduct rapid assessment about the full extent of PMTCT program and services in Denpasar City, Bali. This study located Denpasar City as a capital of Bali with high HIV cases and currently apply PMTCT services. The study conducted through FGDs, in-depth interview and observation in the primary health centers and hospitals. The data was validated by triangulating data from several sources. The results showed that the there is no specific local policy for PMTCT programs and services. There is no PMTCT program management guideline or SOP for PMTCT services at the Health Office and primary health centers. In Denpasar City there are already 5 primary health centers that provide comprehensive HIV and AIDS prevention and treatment services (LKB), and this includes providing PMTCT services consisting of HIV testing and ARV treatment for pregnant women. However, there is no ARV treatment for infant, this service must be obtained at general hospital through a referral mechanism. There is funding from local government (APBD) to buy diagnostic test for HIV and to capacity strengthening of human resources, but no support for further laboratory examinations. The empowerment for midwives to be involved in PMTCT program is limited, there has never been a comprehensive training on PMTCT and no empowerment of private practice midwives for PMTCT. The assistance's activities to ensure ARV adherence is limited. There has been assistance for HIV positive mothers by NGOs in Denpasar City. Women with HIV still get stigma and discrimination from the community and health workers. There are also some challenges in data input, including error in inputting the data that need permission to edit it. It is recommended to improve: the HIV test coverage to $100 \%$ for pregnant women (for the first 90 ); the coverage and quality of ARV treatment (for the second 90); the capacity of PMTCT human resources; the commitment of local government; and data utilization.
\end{abstract}

Keywords: PMTCT, HIV, AIDS, South Sulawesi, Indonesia. 


\section{Introduction}

In Indonesia, an increase in HIV transmission from mother to child causes an increase in HIV infection among new-born. This condition seems to be related to low coverage of HIV testing and prompt antiretroviral (ARV) therapy in pregnant women in Indonesia. Only $28 \%$ pregnant women are HIV tested, and only $13 \%$ of HIV-positive pregnant women received ARV (UNAIDS, 2014). These figures are very far from the target coverage of Elimination of HIV Transmission from Mother to Child (EMTCT) set by WHO in 2015, which among the targets that at least $90 \%$ of all pregnant women living with HIV know their HIV status (WHO, 2015; Wariki et al., 2017). This target can only be achieved if all pregnant women get an HIV test when they visit antenatal care (ANC) services. In fact, the data have shown that the coverage of pregnant women visiting ANC in 2017 has been very high that is 95.4\% (Ministry of Health RI, 2019) his condition, if used properly, constitutes a huge opportunity for Indonesia to achieve the national and global target.

The gaps also occur in the coverage of the EMTCT cascade in Indonesia, which is always low from year to year. This indicates that the program of EMTCT in
Indonesia has not been successful. The trend of coverage of HIV testing for pregnant women in Indonesia in 2015 was from only $<1 \%$ which rose to $28 \%$ in 2017 . The coverage of ARV treatment for pregnant women with HIV in Indonesia is also still low at $8 \%$ in $2015,10 \%$ in 2016 , and $13 \%$ in 2017 . In sharp contrast, at the global level the proportion of HIV-positive pregnant women who receive ARVs in 2017 already reached 80\% (UNAIDS, 2017).

Government policies regarding EMTCT have existed since 2013 (Kementerian Kesehatan RI, 2015). This raises the question why was EMTCT's coverage in Indonesia is still low until now. If this situation persists the program will never achieve its target. With the continuation of HIV transmissions from mother to child, Indonesia has not been able to break the chain of transmission, which implies that the transmission continues into the next generation (Gliddon et al., 2017). The implementation of the EMTCT program apparently has many obstacles including high levels of stigmatization (Ejigu \& Tadesse, 2018), low levels of maternal knowledge about HIV and EMTCT (Deressa et al., 2014; Audureau et al., 2013) , negative perceptions of HIV 
sufferers (Ndege et al., 2016), and the cost of HIV testing and ARV (Muyunda \& et al, 2018). There is a need to explore the reasons of low EMTCT coverage in Indonesia, thus we conducted this rapid assessment in Denpasar as the province with HIV highest prevalence.

\section{Method}

The study conducted in Denpasar, Bali province with qualitative approach by using Rapid Assessment. Method used was focus group discussion (FGD), in-depth interview and observation in the primary health centers and hospitals. The instrument used was the questionnaire that adopted from WHO (2017). The data was taken by triangulating data from several sources (pregnant or breastfeeding women, midwives, HIV program managers in primary health centers, HIV program managers in hospitals, and program managers in the health office), taking into account aspects of the adequacy of participants (10 people are sufficient to accommodate variations of answers and can be managed maximally), as well as several methods (FGD, in-depth interviews, and field observations).

Data collection conducted through some steps: (1) implementation of FGD, in-depth interview and observation, (2) wrote transcript, (3) content analysis, (4) matrix development and (4) discussion development. There are 2 main findings that will be explained in discussions, first what is the program achievements and challenges in the field, to eliminate HIV transmission from mother to child. Second is what should be strategically done to eliminate HIV transmission from mother to child in Denpasar.

\section{Results}

\section{A. Findings on the 2018 HIV PMTCT Cascade Data from Hospitals and Puskesmas.}

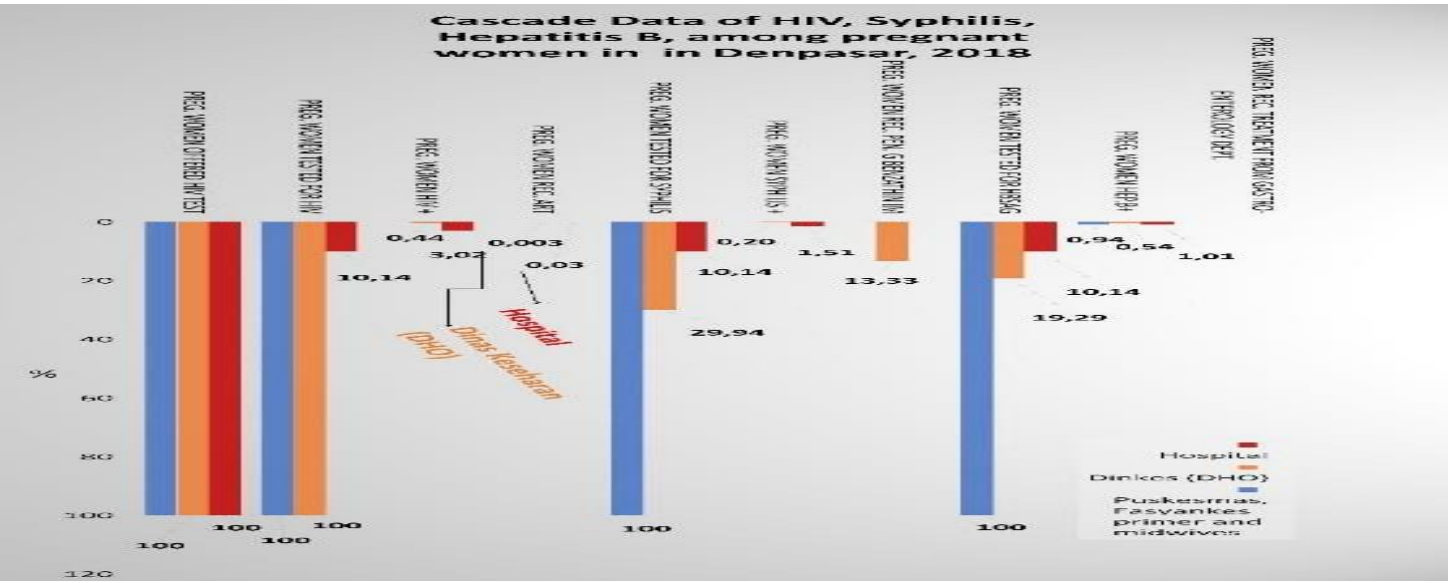


DOI: $10.34305 /$ gemic.v1i1.319

\begin{tabular}{lcccc}
\hline \multirow{2}{*}{ VARIABLE } & \multicolumn{3}{c}{ DENPASAR } \\
\cline { 2 - 5 } & PHC & HEALTHOFFICE & HOSPITAL & TOTAL \\
\hline $\begin{array}{l}\text { Number of women being recommended } \\
\text { for test }\end{array}$ & 1064 & 17173 & 1963 & 20,200 \\
\hline $\begin{array}{l}\text { Number of pregnant women being } \\
\text { tested }\end{array}$ & 1064 & 17173 & 199 & 18,436 \\
\hline $\begin{array}{l}\text { Number of pregnant women being } \\
\text { tested HIV+ }\end{array}$ & 0 & 75 & 6 & 81 \\
\hline $\begin{array}{l}\text { Number of HIV+ pregnant women who } \\
\text { received ART }\end{array}$ & 0 & 52 & 6 & 58 \\
\hline
\end{tabular}

Figure 1. Cascade Data among Pregnant Women in Denpasar, 2018

\section{B. FGD with pregnant or breastfeeding women}

Table 1. Matrix of FGD Results from Pregnant or Breastfeeding Women in Denpasar City

\begin{tabular}{|c|c|c|c|}
\hline Issues & Problem & Causes & Recommendation \\
\hline $\begin{array}{lll}\text { Access } & \text { to } & \text { ANC } \\
\text { services } & & \\
\end{array}$ & $\begin{array}{l}\text { Long queue time (about } \\
30 \text { minutes, if you come } \\
\text { at } 9 \text { will beserved at } 12 \text { ). }\end{array}$ & $\begin{array}{l}\text { PMTCT services only } \\
\text { given once a week. }\end{array}$ & $\begin{array}{l}\text { The frequency of ANC } \\
\text { services with PMTCT } \\
\text { should be added on other } \\
\text { days or attempted with } \\
\text { other media such as } \\
\text { brochures, leaflets, or } \\
\text { videos that could be } \\
\text { showed during waiting } \\
\text { for a call in the ANC } \\
\text { room. At present there is } \\
\text { only astanding banner. }\end{array}$ \\
\hline PMTCT services & $\begin{array}{l}\text { In HIV, syphilis and } \\
\text { hepatitis B test, the } \\
\text { information provided } \\
\text { before the test is very } \\
\text { limited. The complete } \\
\text { information is provided } \\
\text { for those who HIV } \\
\text { positive. }\end{array}$ & $\begin{array}{l}\text { Perhaps it was caused by } \\
\text { limited-service time and } \\
\text { the huge number of } \\
\text { patients, so the information } \\
\text { provided is very limited }\end{array}$ & $\begin{array}{l}\text { Provision of complete } \\
\text { informationcan be given } \\
\text { in the form of a variety } \\
\text { of media outside the } \\
\text { pre-counseling session. }\end{array}$ \\
\hline PMTCT services fee & $\begin{array}{l}\text { There is financialsupport } \\
\text { for the } \\
\text { program }\end{array}$ & - & - \\
\hline $\begin{array}{l}\text { Community point } \\
\text { of view about } \\
\text { people living with } \\
\text { HIV/AIDS }\end{array}$ & $\begin{array}{l}\text { There was a fear of } \\
\text { contracting from } \\
\text { eats, drinks and hold } \\
\text { hands with a people } \\
\text { living with HIV. The } \\
\text { neighbors of } \\
\text { PLWHA also still } \\
\text { discriminate, but } \\
\text { after } 2-3 \text { years they } \\
\text { begin to accept. }\end{array}$ & $\begin{array}{l}\text { There is stigma and } \\
\text { discrimination towards } \\
\text { PLWHA in the } \\
\text { community. }\end{array}$ & $\begin{array}{l}\text { There is a need to } \\
\text { give comprehensive } \\
\text { information about } \\
\text { HIV to the } \\
\text { community to } \\
\text { eliminate stigma and } \\
\text { discrimination }\end{array}$ \\
\hline
\end{tabular}


DOI: $\underline{10.34305 / g e m i c . v 1 i 1.319}$

C. FGD with midwives from primary health centers and private practice.

Table 2. Matrix of FGD Results of Midwives from primary health centers and privatepractices in Denpasar City

\begin{tabular}{|c|c|c|c|}
\hline Issues & Problem & Causes & Recommendation \\
\hline \multirow[t]{3}{*}{$\begin{array}{l}\text { PMTCT services } \\
\text { (mainly HIV test) }\end{array}$} & $\begin{array}{l}\text { All midwives } \\
\text { from primary } \\
\text { health center have } \\
\text { provided PMTCT } \\
\text { services in the } \\
\text { form of HIV } \\
\text { testing for pregnant } \\
\text { women. Midwives } \\
\text { from private } \\
\text { practices (BPM) } \\
\text { refer pregnant } \\
\text { women to the } \\
\text { primary health } \\
\text { center to get an } \\
\text { HIV test, but many } \\
\text { patientsdid not go } \\
\text { because of the long } \\
\text { queue in primary } \\
\text { health center. If } \\
\text { they test, it will be } \\
\text { recorded in the } \\
\text { MCH book. }\end{array}$ & $\begin{array}{l}\text { Midwives from } \\
\text { private practices } \\
\text { (BPM) have not } \\
\text { been trained in } \\
\text { HIVtesting so } \\
\text { pregnant women } \\
\text { should be referred } \\
\text { to the primary } \\
\text { health center, so } \\
\text { there isa } \\
\text { possibility for loss } \\
\text { of follow-up } \\
\text { cases. In addition, } \\
\text { not all midwives } \\
\text { apply universal } \\
\text { precaution (UP) } \\
\text { when serving } \\
\text { pregnant women } \\
\text { because there is } \\
\text { discomfort for the } \\
\text { patient. }\end{array}$ & $\begin{array}{l}\text { There is a need for } \\
\text { OJT and the } \\
\text { provision of } \\
\text { logisticsfor HIV } \\
\text { testing for BPM. } \\
\text { The midwives } \\
\text { should apply UP } \\
\text { when examining } \\
\text { pregnancy or } \\
\text { assisting } \\
\text { childbirth. }\end{array}$ \\
\hline & $\begin{array}{l}\text { There are also } \\
\text { cases of pregnant } \\
\text { women who did } \\
\text { not go to ANC at } \\
\text { all. }\end{array}$ & $\begin{array}{l}\text { Reasons for } \\
\text { pregnant women } \\
\text { not checking for } \\
\text { pregnancy to the } \\
\text { primary health } \\
\text { center or Posyandu } \\
\text { are because the } \\
\text { pregnancy is still } \\
\text { tooearly, there was } \\
\text { no transportation, } \\
\text { no one is taking } \\
\text { care the house, no } \\
\text { husband's } \\
\text { permission }\end{array}$ & $\begin{array}{l}\text { Raise HIV } \\
\text { awarenessof } \\
\text { pregnant women } \\
\text { about the } \\
\text { importance of HIV } \\
\text { testing. } \\
\text { Schedule a } \\
\text { homevisit. }\end{array}$ \\
\hline & $\begin{array}{l}\text { Midwives refuse } \\
\text { PLHAs, or at least } \\
\text { fear in providing } \\
\text { services for them. }\end{array}$ & $\begin{array}{l}\text { There is still stigma } \\
\text { anddiscrimination } \\
\text { in PLWHA. }\end{array}$ & $\begin{array}{l}\text { Training for health } \\
\text { workers to eliminate } \\
\text { stigma and } \\
\text { discrimination in } \\
\text { people with HIV. }\end{array}$ \\
\hline Treatment referral & An HIV-positive & The number of & It is necessary to \\
\hline
\end{tabular}


DOI: $\underline{10.34305 / g e m i c . v 1 i 1.319}$

pregnant woman immediately when she is served at a non-LKB primary health center. cannot get ARV
LKB primary health center only 5 sites. consider the addition of LKB primary

health center, especially those that have HIV positive among pregnant and breastfeeding women, bearing in mind that this situation indicates the number of HIV positive patients among the bridging population and key populations in the area.

\begin{tabular}{|c|c|c|c|}
\hline $\begin{array}{l}\text { Assistance for HIV } \\
\text { positive women } \\
\text { (social support) }\end{array}$ & $\begin{array}{l}\text { Not all primary } \\
\text { health centers can } \\
\text { provide assistanceto } \\
\text { HIV positive } \\
\text { pregnant women }\end{array}$ & $\begin{array}{l}\text { Not all primary } \\
\text { health centers have } \\
\text { LKB capacity, so } \\
\text { they do notyet have } \\
\text { an assistance } \\
\text { mechanism for } \\
\text { HIV positive } \\
\text { women }\end{array}$ & $\begin{array}{l}\text { It is necessary to add } \\
\text { the LKB primary } \\
\text { health center as } \\
\text { mentioned above. }\end{array}$ \\
\hline \multirow[t]{2}{*}{$\begin{array}{l}\text { Adherence for } \\
\text { ARV. }\end{array}$} & $\begin{array}{l}\text { There were } \\
\text { patients who } \\
\text { claimed to be } \\
\text { compliant with the } \\
\text { treatment, butthey } \\
\text { had AIDS } \\
\text { symptoms. }\end{array}$ & $\begin{array}{l}\text { Side effects of } \\
\text { ARVs can cause a } \\
\text { person to stop the } \\
\text { treatment; such } \\
\text { conditions should be } \\
\text { handled by the } \\
\text { assistantwho has a } \\
\text { competency. }\end{array}$ & $\begin{array}{l}\text { Empowerment of } \\
\text { assistants to be able } \\
\text { to provide deeper } \\
\text { counseling about the } \\
\text { side effects of } \\
\text { ARVs, and what to } \\
\text { do if youexperience } \\
\text { this. }\end{array}$ \\
\hline & $\begin{array}{l}\text { There were also } 2 \\
\text { women with HIV } \\
\text { who stop the } \\
\text { treatment because } \\
\text { they feel dizzy and } \\
\text { vomited due to } \\
\text { side effects. } \\
\text { They did not visit } \\
\text { the health workers } \\
\text { because they were } \\
\text { taking care of their } \\
\text { children. }\end{array}$ & & \\
\hline $\begin{array}{l}\text { Recording (MCH } \\
\text { book) }\end{array}$ & $\begin{array}{l}\text { According to the } \\
\text { midwives, all } \\
\text { ANC activities } \\
\text { including HIV } \\
\text { testing are }\end{array}$ & - & - \\
\hline
\end{tabular}


recorded in the

$\mathrm{MCH}$ handbook

\begin{tabular}{llll}
\hline PMTCT service & $\begin{array}{l}\text { The service } \\
\text { guidelines }\end{array}$ & $\begin{array}{l}\text { The absence of SOP } \\
\text { in almost all primary }\end{array}$ & $\begin{array}{l}\text { Develop SOPs that } \\
\text { can be applied at all }\end{array}$ \\
& $\begin{array}{l}\text { Kassikassi and } \\
\text { Kongaya primary } \\
\text { healthcenters, both } \\
\text { health center } \\
\text { only. }\end{array}$ & $\begin{array}{l}\text { for HIV testing and } \\
\text { treatment, including } \\
\text { how to refer patients }\end{array}$ & \\
& & \\
\hline
\end{tabular}

D. FGD with HIV program manager in primary health center in Denpasar City Table 3. Matrix FGD with HIV Program Manager in Primary Health Center in Denpasar

\begin{tabular}{|c|c|c|c|}
\hline Issues & Problemx & Causes & Recommendation \\
\hline \multirow[t]{3}{*}{ PMTCT Services } & $\begin{array}{l}\text { Provincial/City- } \\
\text { level local } \\
\text { guidelines do not } \\
\text { yet exist on } \\
\text { mandatory testing } \\
\text { for HIV, syphilis } \\
\text { and hepatitis B, } \\
\text { but directly refer to } \\
\text { national policies. }\end{array}$ & $\begin{array}{l}\text { The commitment of } \\
\text { the local government } \\
\text { has not been sufficient }\end{array}$ & $\begin{array}{l}\text { Develop provincial } \\
\text { or City PMTCT } \\
\text { Guideline }\end{array}$ \\
\hline & $\begin{array}{l}\text { There are no } \\
\text { guidelines for } \\
\text { HIV care in } \\
\text { newborns }\end{array}$ & & \\
\hline & $\begin{array}{l}\text { There are still } \\
\text { ANC service } \\
\text { flows in primary } \\
\text { health center that } \\
\text { do not explicitly } \\
\text { mention HIV } \\
\text { testing }\end{array}$ & & \\
\hline \multirow[t]{3}{*}{ PMTCT program } & $\begin{array}{l}\text { The ANC target is } \\
\text { too high }\end{array}$ & $\begin{array}{l}\text { The target setting is } \\
\text { not based on the } \\
\text { baseline data of the } \\
\text { previous year }\end{array}$ & $\begin{array}{l}\text { The number of } \\
\text { pregnant women as } \\
\text { ANC target should } \\
\text { bebased on real data }\end{array}$ \\
\hline & $\begin{array}{l}\text { Coverage and } \\
\text { qualityhas not been } \\
\text { achieves }\end{array}$ & $\begin{array}{l}\text { Pregnant women did } \\
\text { not ANC in primary } \\
\text { health center but in } \\
\text { private practice }\end{array}$ & $\begin{array}{l}\text { Maximizing the role } \\
\text { of environmental } \\
\text { midwives, caring } \\
\text { groups for pregnant } \\
\text { women }\end{array}$ \\
\hline & & Pregnant women get & \\
\hline
\end{tabular}


DOI: $\underline{10.34305 / g e m i c . v 1 i 1.319}$

\begin{tabular}{llll}
\hline & \multicolumn{3}{c}{$\begin{array}{l}\text { HIV tested in } \\
\text { hospital }\end{array}$} \\
\hline Logistic availability & $\begin{array}{l}\text { There is once } \\
\text { primary health } \\
\text { centerstock out of } \\
\text { reagent. }\end{array}$ & $\begin{array}{l}\text { Insufficient logistical } \\
\text { management }\end{array}$ & $\begin{array}{l}\text { Strengthening } \\
\text { logistics management } \\
\text { both at the Health } \\
\text { Office and at the } \\
\text { Primary health } \\
\text { centers }\end{array}$ \\
\hline $\begin{array}{l}\text { SIHA recording and } \\
\text { reporting }\end{array}$ & $\begin{array}{l}\text { There were many } \\
\text { times error in data } \\
\text { input }\end{array}$ & $\begin{array}{l}\text { The data input staff } \\
\text { must input the same } \\
\text { data in different } \\
\text { program }\end{array}$ & $\begin{array}{l}\text { Data integration } \\
\text { Supervision }\end{array}$ \\
& $\begin{array}{l}\text { Supervision by the } \\
\text { Health Office } \\
\text { conducted every } \\
\text { month to help HIV } \\
\text { program manager } \\
\text { ifthere is error in } \\
\text { datainput }\end{array}$ & & - \\
\hline
\end{tabular}

E. In-depth interview with HIV Program Manager in the Hospital Table 4. Matrix In-depth Interview with HIV Program Manager in Denpasar

\begin{tabular}{|c|c|c|c|}
\hline Issues & Problem & Causes & Recommendation \\
\hline \multirow[t]{4}{*}{ PMTCT Services } & $\begin{array}{l}\text { There are still } \\
\text { pregnant women } \\
\text { coming to the } \\
\text { hospital not being } \\
\text { HIV tested }\end{array}$ & $\begin{array}{l}\text { Their first ANC } \\
\text { weredone at midwife } \\
\text { fromprivate practice } \\
\text { or private doctor, } \\
\text { with the absence of } \\
\text { HIV testing }\end{array}$ & $\begin{array}{l}\text { Strengthening the } \\
\text { network with } \\
\text { midwives and } \\
\text { doctor from private } \\
\text { practices }\end{array}$ \\
\hline & $\begin{array}{l}\text { There are still } \\
\text { HIV pregnant } \\
\text { women whohave } \\
\text { been referred from } \\
\text { the primary health } \\
\text { center do not get } \\
\text { counseled on HIV }\end{array}$ & $\begin{array}{l}\text { HIV testing in } \\
\text { primary health center } \\
\text { is inadequate in } \\
\text { terms of counseling's } \\
\text { place and counselor's } \\
\text { competency }\end{array}$ & $\begin{array}{l}\text { PMTCT training } \\
\text { formidwives }\end{array}$ \\
\hline & $\begin{array}{l}\text { Pregnant women } \\
\text { thathas been tested } \\
\text { for HIV and are } \\
\text { HIV positive did } \\
\text { not immediately } \\
\text { receive ARV } \\
\text { treatment }\end{array}$ & $\begin{array}{l}\text { Her condition was } \\
\text { unstable by the } \\
\text { presence of } \\
\text { opportunistic } \\
\text { infection (chronic } \\
\text { diarrhea) }\end{array}$ & $\begin{array}{l}\text { Make standard } \\
\text { procedures for HIV } \\
\text { patient with } \\
\text { Opportunistic } \\
\text { infection }\end{array}$ \\
\hline & There was one case & Lack of family & Socialization to the \\
\hline
\end{tabular}




\begin{tabular}{|c|c|c|c|}
\hline & $\begin{array}{l}\text { where a child did } \\
\text { notHIV tested }\end{array}$ & $\begin{array}{l}\text { awareness about the } \\
\text { need for HIV testing } \\
\text { in children }\end{array}$ & $\begin{array}{l}\text { importance of HIV } \\
\text { testing in children of } \\
\text { HIV positive } \\
\text { mother }\end{array}$ \\
\hline & & $\begin{array}{l}\text { PCR to HIV test for } \\
\text { children is not } \\
\text { available }\end{array}$ & $\begin{array}{l}\text { RSUD needs to be } \\
\text { equipped with a } \\
\text { PCRdiagnostic tool }\end{array}$ \\
\hline Treatment referral & $\begin{array}{l}\text { Children born from } \\
\text { an HIV mother do } \\
\text { not get prophylactic } \\
\text { treatment }\end{array}$ & $\begin{array}{l}\text { Prophylactic ARVs } \\
\text { are not available for } \\
\text { children so they must } \\
\text { be referred }\end{array}$ & $\begin{array}{l}\text { RSUD must be able } \\
\text { to conduct early } \\
\text { infant diagnostics } \\
\text { (EID) and have } \\
\text { prophylactic ARVs } \\
\text { for children }\end{array}$ \\
\hline $\begin{array}{l}\text { Assistance to HIV } \\
\text { pregnant women }\end{array}$ & $\begin{array}{l}\text { There has not been } \\
\text { an assistance or } \\
\text { support group for } \\
\text { HIV positive } \\
\text { pregnant women }\end{array}$ & $\begin{array}{l}\text { Focus on building } \\
\text { CST team in the } \\
\text { hospital }\end{array}$ & $\begin{array}{l}\text { Establish an HIV } \\
\text { positive pregnant } \\
\text { women assistance } \\
\text { group, work together } \\
\text { with hospital and } \\
\text { NGOS in Denpasar }\end{array}$ \\
\hline \multirow[t]{2}{*}{ Adherence to ARV } & $\begin{array}{l}\text { CD4 examination } \\
\text { for pregnant } \\
\text { women cannot be } \\
\text { done at thehospital }\end{array}$ & $\begin{array}{l}\text { CD4 reagent is not } \\
\text { available }\end{array}$ & $\begin{array}{l}\text { RSUD provide } \\
\text { CD4 reagent }\end{array}$ \\
\hline & $\begin{array}{l}\text { Viral load } \\
\text { examination for } \\
\text { pregnant women } \\
\text { cannot be done in } \\
\text { thehospital }\end{array}$ & $\begin{array}{l}\text { Viral load reagents } \\
\text { (such as from Abbott } \\
\text { and Cobas) are not } \\
\text { available }\end{array}$ & $\begin{array}{l}\text { RSUD provide } \\
\text { viralload reagent }\end{array}$ \\
\hline $\begin{array}{l}\text { Recording (MCH } \\
\text { book). }\end{array}$ & $\begin{array}{l}\text { For pregnant } \\
\text { women who came } \\
\text { to primaryhealth } \\
\text { center for the first } \\
\text { ANC, the HIV } \\
\text { test results are } \\
\text { recorded in MoH } \\
\text { book, while those } \\
\text { who have their first } \\
\text { contact at the } \\
\text { midwives from } \\
\text { private practices } \\
\text { are not recorded }\end{array}$ & $\begin{array}{l}\text { Midwives from } \\
\text { private practices } \\
\text { (BPM) do not } \\
\text { conduct HIV test }\end{array}$ & $\begin{array}{l}\text { Training or OJT for } \\
\text { midwives of private } \\
\text { practice on HIV } \\
\text { testing as well as } \\
\text { training for } \\
\text { recording. }\end{array}$ \\
\hline $\begin{array}{l}\text { PMTCT Service } \\
\text { Guidelines }\end{array}$ & $\begin{array}{l}\text { There is nothing } \\
\text { explicit, and there } \\
\text { isonly Perda HIV } \\
\text { No. } 2 / 2016\end{array}$ & $\begin{array}{l}\text { PMTCT is still } \\
\text { considered not a } \\
\text { priority for specific } \\
\text { policy }\end{array}$ & $\begin{array}{l}\text { There is a need to } \\
\text { develop Regulation } \\
\text { from Head of City } \\
\text { (Perbup) }\end{array}$ \\
\hline
\end{tabular}


F. In-depth Interview with HIV Program Manager in Health Office Table 5. Matrix In-depth Interview with HIV program manager in Denpasar City's Health Office

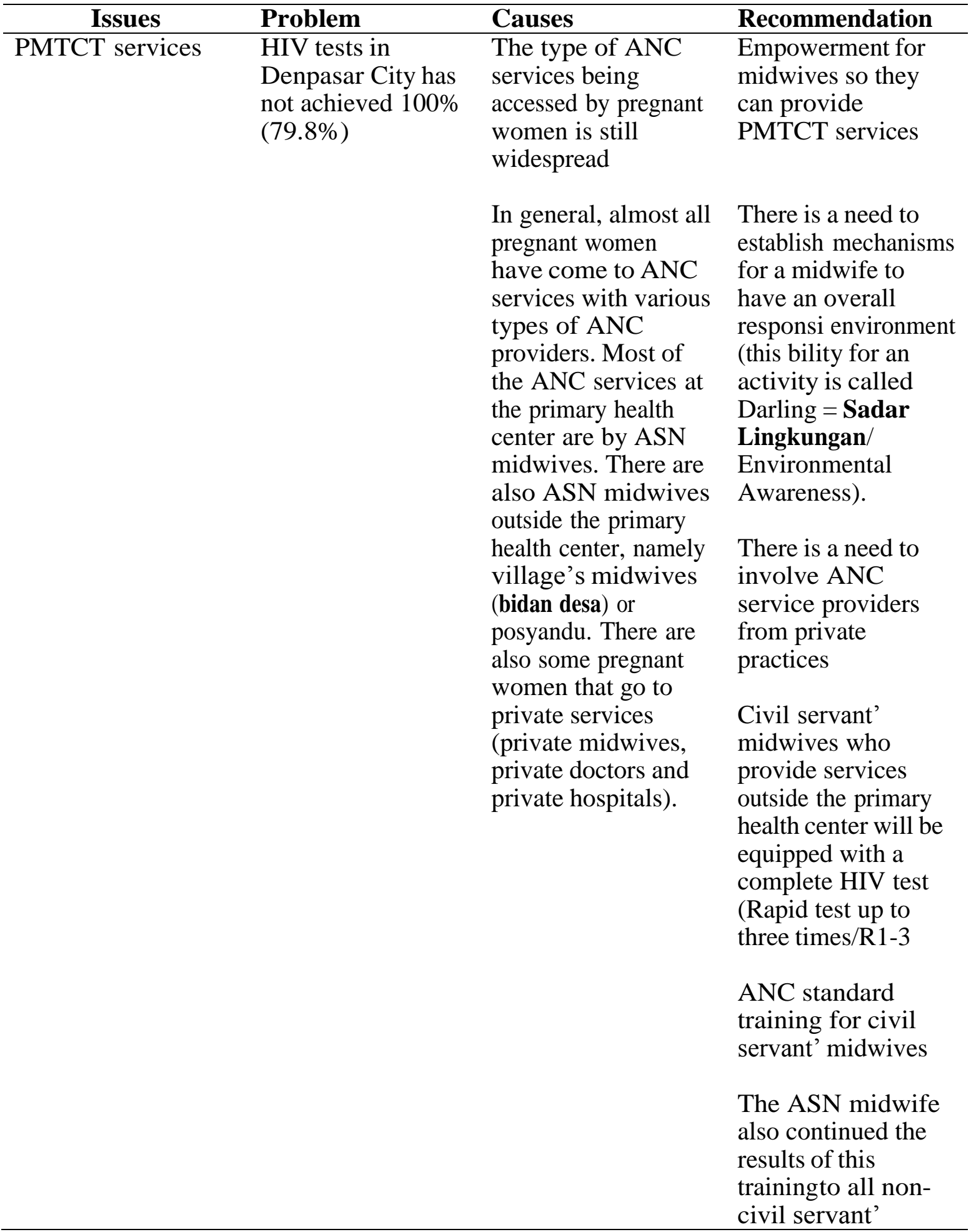


Primary health centerin Denpasar cannot provide ARV

RSUD

Salewanggang cannot assess the compliance to ARV

RSUD

Salewangang does not have PMTCT services for children born from HIV positive mother

PMTCT Program
HIV testing at the primary health centeris only 1 time if the R-1 is negative. If $\mathrm{R}-1$ is positive, confirmto R-2 and R-3 at the hospital

The civil servant' midwives who provide ANC services outside the midwives through the mechanism of IBI meetings starting from the City levelto the lowest level atthe branch level.

There is a need to establish OJT (on thejob training) mechanism.

There is no ARV Improve the available in primary health center in Denpasar competency of primary health center in Denpasar City to become LKB that canprovide ARV

There is no reagent Improve the available to examine competency of CD4 and viral load diRSUD

Salewangang and should be referred to Wahidin General Hospital in Denpasar RSUD in Denpasar forCD 4 and viral loadexamination

There is no ARV for pediatrics and early infant diagnostic (EID) available and should be referred to Wahidin General Hospital in Denpasar In the planning, there is only request $\mathrm{R} 1$

\section{HIV testing with} theRapid Test method can be done in full (3tests) in all primary health center and allother services 
primary health centercan have tests but arenot complete (1 test only), which if foundpositive for confirmation will be referred to the primary health center

Management (HR, funding, logistic)
There is still a shortage of test kits and the availability of ARV

Patients do not want to take ARV in Salewangang Hospital

There are still healthworkers who do notunderstand PMTCT services

Lack of capacity and numbers of programmanagers

Unavailability of assistance and support group

\section{There is constraintsin Training for HIV PMTCT funding program manager}

Pharmacy for ARC and other drug is located in one place

Disclosure of HIV status

Stigma and discrimination

Training held previously did not sufficient

Availability of competent human resources

Competency-based training

Limited OJT that attended by the program manager

Lack of funds to develop human resource as HIV program manager

Provide similar opportunity to all HIV program manager to attend OJT

Commitments for PMTCT services arejust beginning for standard service
Preparing outreach groups and assistants in collaboration with NGOs to reach and assist pregnant women to obtain information about HIV and assistance for HIV positive pregnant women 


\begin{tabular}{|c|c|c|c|}
\hline Coordinativemeeting & $\begin{array}{l}\text { There is still a lack } \\
\text { ofcommunication }\end{array}$ & $\begin{array}{l}\text { Coordination with } \\
\text { program managers at } \\
\text { the primary health } \\
\text { centers. Relations } \\
\text { between the primary } \\
\text { health center and the } \\
\text { hospital went } \\
\text { smoothly through the } \\
\text { WA group }\end{array}$ & $\begin{array}{l}\text { Hold regular } \\
\text { coordination meeting }\end{array}$ \\
\hline Policy & $\begin{array}{l}\text { The local policy } \\
\text { forPMTCT is not } \\
\text { explicitly } \\
\text { mentionedbut there } \\
\text { is a regulation on } \\
\text { HIV, Perda No } \\
2 / 2016\end{array}$ & $\begin{array}{l}\text { Depend to national } \\
\text { policy }\end{array}$ & $\begin{array}{l}\text { Develop local } \\
\text { guidelines for } \\
\text { PMTCT services in } \\
\text { Denpasar City }\end{array}$ \\
\hline
\end{tabular}

\section{Discussion}

This assessment focuses on eliminating HIV transmission from mother to child. The elimination means that there is no HIV transmission from mother to baby. This is only possible with $100 \%$ coverage of pregnant women who are tested for HIV in one working area and all HIV positive pregnant women should get ARV treatment immediately. Therefore, HIV transmission from pregnant women to their babies can be prevented completely. In this assessment, several progresses have been found in the Prevention of HIV Transmission from Mother to Child (PMTCT), in Denpasar. However, it appears that the current program achievement still has many obstacles that need to be addressed immediately. Fortunately, there is hope to implement the PMTCT program in order to have high coverage and quality to achieve zero new infection in newborns. This fourth section will comprehensively discuss the achievement and challenges of the PMTCT program's performance, and strategic steps to eliminate HIV transmission from mother to baby.

1. Achievements and Challenges to Eliminate HIV Transmission from Mother to Child, in Denpasar.

\subsection{Policy.}

The national and local policies on HIV and AIDS prevention and control have existed. Regarding PMTCT, there is only available a national policy, Minister of Health Regulation No.52/2017 that 
mandated all health facilities to implement elimination of HIV, syphilis and Hepatitis B transmission from mother to child. The local policies on PMTCT program management guidelines and standard operational procedures (SOPs) are not yet available. The government has issued Minister of Health Regulation No. 51/2013 on HIV and AIDS Management Since 2010, South Sulawesi has released the Local Regulation (Perda) No. 4/2010 about the Prevention and Control of HIV and AIDS. For HIV treatment, at the national level there is a Minister of Health Regulation No. 87/2014 and it should be implemented in all health facilities, including primary health center. Primary health center that implement HIV testing and treatment called comprehensive sustainable service (Layanan Komprehensif Berkesinambungan/ LKB), unfortunately, in Denpasar City the number of LKB primary health center is still limited compared to the need for PMTCT services include HIV testing for pregnant women, if she is HIV positive, she will immediately treated with ARV, as well as for ARVs and HIV testing for children.

\subsection{Program}

Management

\section{Guidelines.}

There are no program management guidelines for HIV program managers, especially for managers at the Health Office level and at the primary health center level. There are no standardized SOP for PMTCT services at the hospitals, primary health centers and midwives from private practices for pregnant women. The service procedures or flow of PMTCT are still different between the observed primary health centres. Integrated internal referral between programs at the primary health centre is already running, for example patients with abnormal vaginal discharge can be tested for syphilis, tuberculosis patients are required to have an HIV test. 


\subsection{Comprehensive Sustainable}

Services.

In Denpasar City, there are 5 primary health centers that are able to provide HIV and AIDS prevention and treatment, including for PMTCT services. It seems that Denpasar City still needs the addition of a primary health center with Comprehensive Sustainable Services (LKB) to be able to serve HIV positive pregnant women. However, there is no strong mechanism to decide the criteria for the establishment of the LKB primary health center, there is no supervision from the center. Up to now, the criteria used by the Health Office to add LKB primary health center is based on the readiness of human resources and logistics as well as the presence of HIV patients.

\subsection{Program Coverage.}

The coverage of HIV testing in pregnant women has not reached $100 \%$. The Health Office in Denpasar City has not involved private hospitals and clinics yet. Those facilities only refer pregnant women to undergo HIV testing to primary health center or local public hospital but most of these pregnant women did not test HIV. It is estimated that if the infrastructure and capacity of PMTCT's programs and services are still like this, the next coverage will not be able to reach $100 \%$. The Health Office in Denpasar City is planned to conduct training for private sector (hospitals, clinics, midwives) to implement PMTCT services at the end of January 2020 with support from UNICEF. The HIV testing in the Daya Hospital has been widespread to all community, including pregnant women, but it has not been able to reach its full extent so there are still children who are infected with HIV. Children with chronic diarrhea and fever, oral candidiasis, bronchopneumonia will also be tested for HIV and it proves that not all pregnant women were tested for HIV. Besides providing the HIV testing at ANC services, patients who come to the hospital with diarrhea, TB, STIs, swollen glands, BB dropped dramatically, 
low Hemoglobin, Hepatitis B, transvestites and MSM will also be tested for HIV. To check viral load, they will be referred to Local Health Laboratory (Labkesda) and it is free for patients who have just been treated for 6 months. Another problem in examining pregnant women is that they do not have complete knowledge about HIV before testing and the health worker only emphasizes that this is mandatory. The reason is because there are many patients and long queues so they cannot provide complete information to their patients. As a result, many pregnant women who have been tested for HIV do not fully understand why the test should be carried out.

\subsection{Funding.}

Funds are available for the PMTCT program, except for further laboratory examinations. The availability of logistics and funding so far has been good, because it has been budgeted by the local government and patients to have health insurance, but if possible BPJS or APBD support further examinations for HIV patients, such as liver function (SGOT, SGPT), creatinine and $X$ rays. Even though there was one case where a woman did not pay BPJS premium, thus delaying ANC services.

\subsection{Positive Rate.}

The proportion of HIV positive among pregnant women cannot be known exactly given the data collected is still in limited scope. It is suspected that the data obtained are still underestimate. According to PMTCT data in 2019, the coverage of pregnant women who tested for HIV in Denpasar City was still below 80\%, pregnant women having HIV positive status ranging from $0.03 \%$ to $0.12 \%$. Pregnant women who received ARV therapy were $100 \%$ in Denpasar City.

\subsection{Private Sector Involvement.}

Empowerment of midwives to be involved in the PMTCT program is still limited. In terms of human resources, all midwives in primary health center in Denpasar City have been able to do so, in contrast to the 
midwives from private practices who have not received training, so their patients must be referred to the primary health center. There is a weakness for that referral system where patients did not come to primary health center as referred. There are several reasons given by patients who did not come to the primary health centers, including long queues, long distances and no one to assist their children in homes. A pregnant woman with HIV will be given ARV at the LKB's primary health center and given an explanation by a doctor. In Denpasar, a patient with HIV from a non-LKB primary health center, she will be referred to the LKB Puskesmas. Whereas in Denpasar, all primary health centers have not been LKB, thus patients will be referred to the City Hospital which has risk to be non-compliant to take medication due to access and side effects.

\subsection{Support Mechanism.}

Assistance mechanisms for compliance with medication are still limited. For HIV testing, the primary health centers do not assist or accompany positive pregnant women and will only be accompanied by NGOs in Denpasar if they are HIV positive, especially to monitor ARV adherence. In Daya Hospital, an obstetric gynecologist who has been trained was transferred to other places so there are no skilled doctors. For midwives, all of them can provide the services well, from $\mathrm{MCH}$ unit they will be referred to the laboratory for tests and if positive, they will be counseled by nurses. However, head of unit or program managers rarely have the opportunity to attend training.

\subsection{Stigma and Discrimination.}

Stigma and discrimination against HIV women is still high. They HIV experienced stigma and discrimination from health workers (midwives and dentists) and this was also admitted by the midwives from primary health centers and private practices. The midwives rejected HIV patients or even if they did not refuse, they felt worried in serving them. Besides 
from health workers, HIV women were also discriminated by the community around their homes, so they closed their status. Fortunately, there was one case that after 2 years the neighbors could accept their existence because of their personal approach and maintain good communication. In Denpasar there is an HIV positive woman who does not want to take drugs to avoid stigma and discrimination from her environment so that she took other hospital to take ARV. In Denpasar, there were social factors such as the low involvement of men to access ANC in health facilities.

\subsection{Data input.}

There are some obstacles in data input. HIV data is recorded manually and then uploaded at the end of the month. If an input error occurs after the report is uploaded, then it cannot be opened, they should contact health office staff to open and edit it. Data from each unit has not been integrated, for example if one person checks in several units then the recording staff must re-input all her/his individual characteristics such as place and date of birth, sex, etc. For supervision there is no standard for program management and supervision.

2. Strategic Steps to Eliminate HIV Transmission from Mother to Child, in Denpasar City.

2.1. Improve coverage of pregnant women to be $100 \%$ HIV tested.

The coverage of pregnant women tested for HIV must be $100 \%$ and it has been done by primary health centers, but it has not been done by private services (clinics, hospitals and midwives). For primary health centers that have LKB, it is necessary to provide refreshing training to strengthen knowledge and skills to provide PMTCT services.

2.2. Improve the quality of ARV treatment in service site.l

To improve the quality of HIV treatment, a LKB primary health centers must have refreshing training related to PMTCT to increase the coverage of HIV test 
and treatment, including test and treatment for infants. It also needs to be considered to increase the number of LKB primary health center in Denpasar, there must be a minimum of 1-2 LKB primary health center, with consideration of the capacity, capability and burden of the manager which must begin with a site assessment. To ensure adherence for ARV, actually there is assistance, but there is a need to strengthen the capacity of the assistants in several aspects, first in terms of adherence to take medication, second, in handling complications and thirdly in women who are taking medication must be able to handle their daily activities. It would be very difficult to expect daily supervision from health workers, so it is highly needed a social support from peers.

\subsection{Improve the Capacity of Human}

\section{Resources in PMTCT Services.}

Human resources should get competency-based training suitable to service site in one teamwork, because OJT is still very limited. In addition, management guidelines and SOPs are needed at each service site (hospitals, health centers, midwives from privat e practices).

\subsection{Commitment from Local Government.}

Local governments should conduct community-based training, for example the Darling program (Bidan Sadar Lingkungan) that is already running in Denpasar City where the midwives from primary health centers shows curiosity to all pregnant women to childbirth by using the $\mathrm{MCH}$ book as a standard. In addition, the local government is also expected to be able to increase human resource capacity and budget allocation.

\subsection{Data Input.}

PMTCT data is not available at all levels, but directly to the central.

\section{Conclusion}

The results conclude that there is no specific local policy for PMTCT programs and services. There is no PMTCT program management guideline or SOP for PMTCT services at the Health Office and primary 
DOI: $\underline{10.34305 / g e m i c . v 1 i 1.319}$

health centers. In Denpasar City there are already 5 primary health centers that provide comprehensive HIV and AIDS prevention and treatment services (LKB), and this includes providing PMTCT services consisting of HIV testing and ARV treatment for pregnant women. However, there is no ARV treatment for infant, this service must be obtained at Wahidin General Hospital through a referral mechanism. There is funding from local government (APBD) to buy diagnostic test for HIV and to capacity strengthening of human resources, but no support for further laboratory examinations. The empowerment for midwives to be involved in PMTCT program is limited, there has never been a comprehensive training on PMTCT and no empowerment of private practice midwives for PMTCT. The assistance's activities to ensure ARV adherence is limited. There has been assistance for HIV positive mothers by NGOs in Denpasar City. Women with HIV still get stigma and discrimination from the community and health workers. There are also some challenges in data input, including error in inputting the data that need permission to edit it.

\section{Suggestion}

It is recommended to improve: the HIV test coverage to $100 \%$ for pregnant women (for the first 90); the coverage and quality of ARV treatment (for the second 90); the capacity of PMTCT human resources; the commitment of local government; and data utilization.

\section{Reference}

Audureau, E., Kahn, J. G., Besson, M.-H., Saba, J., \& Ladner, J. (2013). Scaling up prevention of mother-to-child HIV transmission programs in sub-Saharan African countries: a multilevel assessment of site-, program- and country-level determinants of performance. BMC Public Health, 13, $286 . \quad$ https://doi.org/10.1186/14712458-13-286

Deressa, W., Seme, A., Asefa, A., Teshome, G., \& Enqusellassie, F. (2014). Utilization of EMTCT services and associated factors among pregnant women attending antenatal clinics in Addis Ababa, Ethiopia. BMC Pregnancy and Childbirth, 14(1), 328. https://doi.org/10.1186/1471-2393-14328

Ejigu, Y., \& Tadesse, B. (2018). HIV testing during pregnancy for prevention of mother-to- child transmission of HIV in Ethiopia. PLoS One, 13(8). https://doi.org/http://dx.doi.org/10.137 1/journal.pone.0201886. 
Gliddon, H. D., Peeling, R. W., Kamb, M. L., Toskin, I., Wi, T. E., \& Taylor, M. M. (2017). A systematic review and meta-analysis of studies evaluating the performance and operational characteristics of dual point-of-care tests for HIV and syphilis. PMC, 93(4), 3-15. https://doi.org/10.1136/sextrans2016-053069

Kementerian Kesehatan RI. (2015). Pedoman pelaksanaan pencegahan penularan HIV dan sifilis dari ibu ke anak bagi tenaga kesehatan. Jakarta: Kementerian Kesehatan.

Ministry of Health RI. (2019). Indonesia health profile at 2018.

Muyunda, B., Mee, P., Todd, J., Musonda, P., \& Michelo, C. (2018). Estimating levels of HIV testing coverage and use in prevention of mother-to-child transmission among women of reproductive age in Zambia. Archives of Public Health, 76(1), 80. https://doi.org/10.1186/s13690-0180325-x

Ndege, S., Washington, S., Kaaria, A., Prudhomme-O'Meara, W., Were, E., Nyambura, M., ... Braitstein, P. (2016). HIV prevalence and antenatal care attendance among pregnant women in a large home-based HIV counseling and testing program in Western Kenya. PLoS One, 11(1). https://doi.org/https://doi.org/10.1371/j ournal.pone. 0144618

UNAIDS. (2014). To help end the AIDS epidemic. Retrieved from http://www.unaids.org/sites/default/fil es/media_asset/90-90-90_en.pdf.

UNAIDS. (2017). Prevention of mother-tochild transmission ( PMTCT) of HIV.
Retrieved from https://www.avert.org/professionals/hi $\mathrm{v}-$

programming/prevention/preventionmother- child

Wariki, W., Ota, E., Mori, R., Wiysonge, C., Horvath, H., \& Read, J. (2017). Interventions for preventing motherto-child HIV transmission: protocol of an overview of systematic reviews. BMJ Open, 7(6), e014332. https://doi.org/10.1136/bmjopen-2016014332

WHO. (2015). EMTCT strategic vision 2010-2015: preventing mother-tochild transmission of HIV to reach the UNGASS and Millennium Development Goals. World Health Organization. https://doi.org/10.1016/j.apmr.2011.11 .034 
It'S

eMICH $D_{x}$ $1^{\text {st }}$ INTERNATIONAL SEMINAR OF GENDER, MATERNAL, EQUITY AND CHILD HEALTH

DOI: 10.34305/gemic.v1i1.319 